\title{
TRANSPORT CORRIDORS AS AN IMPORTANT ELEMENT OF THE SUSTAINABLE DEVELOPMENT POLICY WITH PARTICULAR EMPHASIS ON RAILWAYS
}

\author{
Janusz Myszczyszyn ${ }^{1}, \mathrm{PhD}$ \\ ${ }^{1}$ West Pomeranian University of Technology in Szczecin, Faculty of Economics
}

\begin{abstract}
The development and shaping of transport systems in the international and national system is important both in the aspect of globalisation processes and the aspect of sustainable development. The initiative of a New Silk Route (NSR) may be a good example for analysing this process. The "One Belt, One Road Initiative" is intended to ensure even closer contact between the Middle Kingdom and the Western world.

In order to achieve economic objectives, it is essential to build and modernise the global transport network, both at sea and on land. The importance of the problem is demonstrated by the "Roadmap to a Single European Transport Area - Towards a competitive and resource efficient transport system" adopted by the European Commission in 2011 (the so-called "white book"). The so-called transport corridors, whose railway will be an important link, will play a special role in the implementation of this objective and in the construction of the NSR. Modern rail transport can be cheaper and faster than road and sea transport, fitting much better into the concept of sustainable development. Using statistical data and plans for the development of the transport infrastructure, the author demonstrates a chance for the growth of the importance of railways, which, at the end of the twentieth century, experienced a clear regression.
\end{abstract}

Key words: the New Silk Route (NSR), transport corridors, railway, sustainable development. JEL code: Q01, Q55, Q56, R40.

\section{Introduction}

Undoubtedly, the new Silk Road is a huge project of building and modernising the existing transport infrastructure, as well as an opportunity to shape international relations and global governance based on new principles and values. The project is open to all nations and its "win-win" formula indicates that each party (country) can benefit.

Since the announcement of the initiative in 2013, China has concluded more than 130 bilateral transport agreements, more than 350 international roads have been opened for passenger and freight transport, more than 4,000 direct connections with 43 countries, 39 rail links with Europe, and six more transport corridors between Europe and Asia are under construction, and new connections in central and eastern Africa are being developed.

The initiative, which is still open, is already engaged in several dozen countries, which have nearly 4.4 billion inhabitants, producing $55 \%$ of the world's GDP, with nearly $3 / 4$ of energy resources at their disposal.

A huge population and the diversification of economic development can contribute to an increase in trade flows and social welfare, while respecting cultural diversity, all the more so as the project assumes the free movement of factors of production, and one of the basic objectives is the achievement of diversified, independent and sustainable development of individual countries (Vision and Actions on Jointly Building..., 2015)

In this respect, the development of an effective transport network, including the so-called corridors (including railway corridors), which may lead to the strengthening of economic, social and cultural contacts between the two distant ends of the two continents, remains important: Europe and Asia, but also Africa. To this end, the European Commission adopted the White Paper on 28 March 2011. The document sets a target of reducing greenhouse gas emissions in the transport sector by at least $60 \%$ by 2050 compared to 1990 (White Paper, 2011). Regulation (EU) No 1316/2013 of the

\footnotetext{
${ }^{1}$ Corresponding author. jmyszczyszyn@zut.edu.pl
} 
European Parliament and of the Council provides, inter alia, that trans-European networks should facilitate cross-border connections, foster greater economic, social and territorial cohesion and contribute to improving the competitiveness of the social market economy and to combating climate change (Regulation (EU) No 1316/2013, 2013).

Research hypothesis: the development of transport corridors, including the development of highspeed railways, is an important initiative and an opportunity to ensure sustainable economic and social development, including the NSR.

The aim of this paper is to analyse the role of the railway in creating transport corridors and promote sustainable development, as well as to assess the global initiative itself, which is the new Silk Road.

The tasks of the research: 1) review and analysis of statistical data on global trade as well as the development of the railway network; 2) collecting and analysing available studies and research on the new Silk Road as well as sustainable development; 3 ) review of Regulations of the European Parliament and of the Council (EU) regarding the extension of transport corridors and the review of the White Paper on 28 March 2011; 4) assessment of prospects for the expansion of the railway network in China and the expansion of rail corridors in Europe; 5) defining the role of railway in the policy of sustainable development in the aspect of building the new Silk Road.

The following research methods were used in this article: review of scientific literature, Regulations of the European Parliament and the Council, analysis of statistical data; comparative analysis and synthesis techniques.

\section{Research results and discussion}

The World Trade Organisation (WTO) statistics show that in 2016 the world economy recorded a decline in GDP of $2.3 \%$ (down by $2.7 \%$ in 2015) (World Trade Statistical Review, 2017, 2016). Despite a slight increase in the volume of trade compared to 2015, the value of trade in 2016 decreased. This process has been accompanied by a reduction in the prices of many raw materials (e.g. oil). This result is far from expectations, and one of the reasons for the slowdown in international trade is seen, for example, in the slowdown in China's economic growth rate (World Trade Statistical Review. 2016).

Europe, Asia and North America accounted for more than $83 \%$ (2016) of the world's total trade gap (88 \% in 2015). If we look at the five largest economies in the world (China, the USA, Japan, Germany, France), they account for over $38 \%$ of the total world trade in goods. It should be noted that in 2016, for the first time since 1996, China's share in world trade in goods turnover fell to $11.8 \%$ (from $12.25 \% 2015$ ), which does not change the fact that the country has the potential.

- China's economy is strongly linked to many areas on the world economic map. Analysing only the last four years of foreign trade, the following tendencies for the Chinese economy can be observed (Fig. 1):

- The value of exports in goods trade exceeded USD 2.34 trillion (2014), USD 2.27 trillion (2015) and USD 2.098 trillion (2016);

- the value of goods exports accounted for $14 \%$ of global exports (2015) and $13.2 \%$ (2016);

- imports of goods amounted to USD 1.95 trillion (2014), USD 1.68 trillion (2015), USD 1.58 trillion (2016);

- the value of imports of goods accounted for $10.1 \%$ of global imports (2015) and $9.8 \%$ (201); 
- Asia (largely due to the activity of China) outstripped Europe for the first time in its history in the share of global trade ( $36.17 \%$ against $36.15 \%$ of Europe).

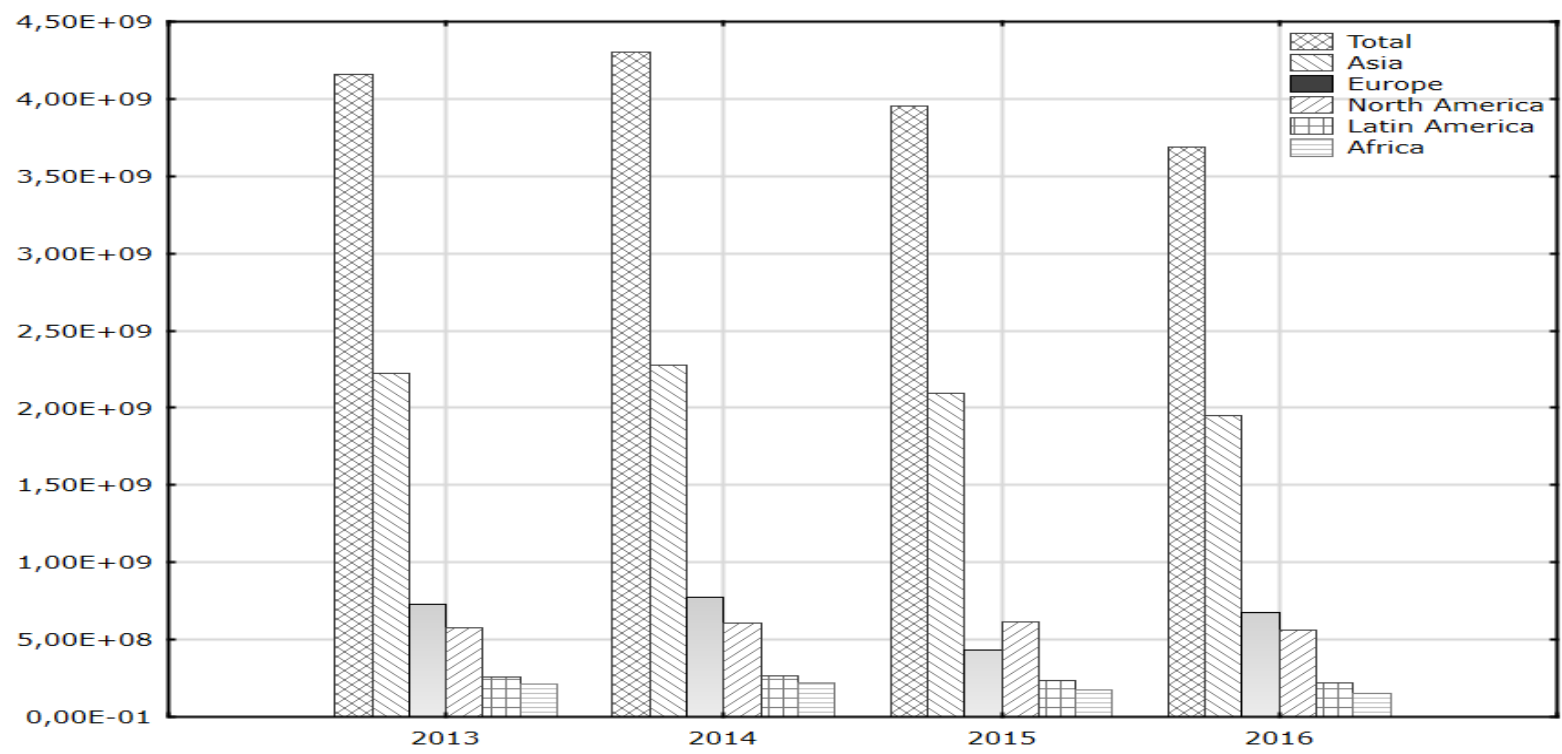

Source: author's calculations based on: China Statistical Yearbook, (2014-2017), National Bureau of Statistics of China, China Statistics Press, Beijing, Tab. 11-6 Value of imports and exports by country (region) of origin/destination

Fig. 1. The value of China's foreign trade turnover, including selected regions of the world (thou. USD 2013-2016)

It should be added that apart from the increase in China's share in international trade, the structure of exports and imports is changing, for example: in 1980, the value of exports amounted to USD 18.1 billion (including unprocessed goods, which accounted for $50.3 \%$ ); in 2000, the value of exports reached USD 249.2 billion already (unprocessed goods accounted for only $10 \%$ ); in 2010, the value of exports rose to USD 1577.7 billion (unprocessed goods accounted for only $5.2 \%$ ); and in 2015, the result was USD 2273.4 billion (unprocessed goods accounted for only $4.5 \%$ ). The value of Chinese imports amounted to over USD 20 billion in 1980 (including unprocessed goods, which accounted for $34.7 \%$ ), in 2000 - USD 225 billion already, in 2010 - USD 1,396.24 billion, and in 2015 - USD 1,679.56 billion (including unprocessed goods, which accounted for $28.1 \%$ ).

In 2015, Asia has suffered the slightest decline in exports compared to the rest of the world. The value of foreign investments also grew: in 2015, it amounted to over USD 2657.5 billion and was $11.7 \%$ higher than in 2014 (China Statistical Yearbook, 2016).

China is also one of the main trading partners of the European Union (2nd place after the USA), as is the case for many EU Member States. In 2012 alone, more than 90 million Mt of goods were mentioned by these two partners. Growing trade volumes and fierce competition are encouraging new transport investments that would, on the one hand, allow for fast and undistorted replacement, and, on the other hand, lead to a reduction in freight costs and fit in with the sustainable development strongly advocated by the Western world.

The emergence of many transport nodes is an opportunity to develop intermodal transport and increase trade between different regions of the world, according to the concept of comparative costs.

\section{Revitalisation of railways. Importance of transport corridors}

Railways were one of the most important innovations in the conditions of the nineteenth and early twentieth century (Myszczyszyn, 2013), and are currently experiencing a clear crisis. Given the 
development of deep-sea, wheeled and air transport, they have a chance to play a significant role in the creation of the so-called transport corridors.

Transport corridors play a special role in the development of the transport and communication network. According to Ch. Kunaka, for thousands of years, R. Carruthers' trade and transport corridors have enabled connections between regions, countries and continents. Areas with a welldeveloped transport network provided an opportunity for fast and efficient transport, and often achieving significant economies of scale ensured relatively low transport costs (Kunaka Ch., Carruthers R., 2014).

Rail is to be an important element of Europe's connection with China, although as T. Puls from the Institut der deutschen Wirtschaft points out, foreign trade statistics show that over $90 \%$ of the value of trade with China is currently carried out using maritime transport (Puls T., 2016). Despite the many advantages of sea transport, its big disadvantage is the transport time, which is on average (in contacts with Europe) 30-35 days.

Statistics confirm that rail transport still accounts for a small proportion compared to other modes of transport. For example, in 2012, in China-EU trade, maritime transport was the main mode of transport and accounted for nearly $62 \%$ of total transport, air transport accounted for $23 \%$ and road and rail transport only $7.5 \%$, including $0.4 \%$ rail transport (S. Frederick Starr S. F., Cornell S. E., Norling N., 2015).

The Figure (Fig. 2) shows the increase in the length of railway routes, and the share of rail transport in China's total freight ( \% tkm). The percentage was $13.32 \%$ (2015) and 12.75 (2016).

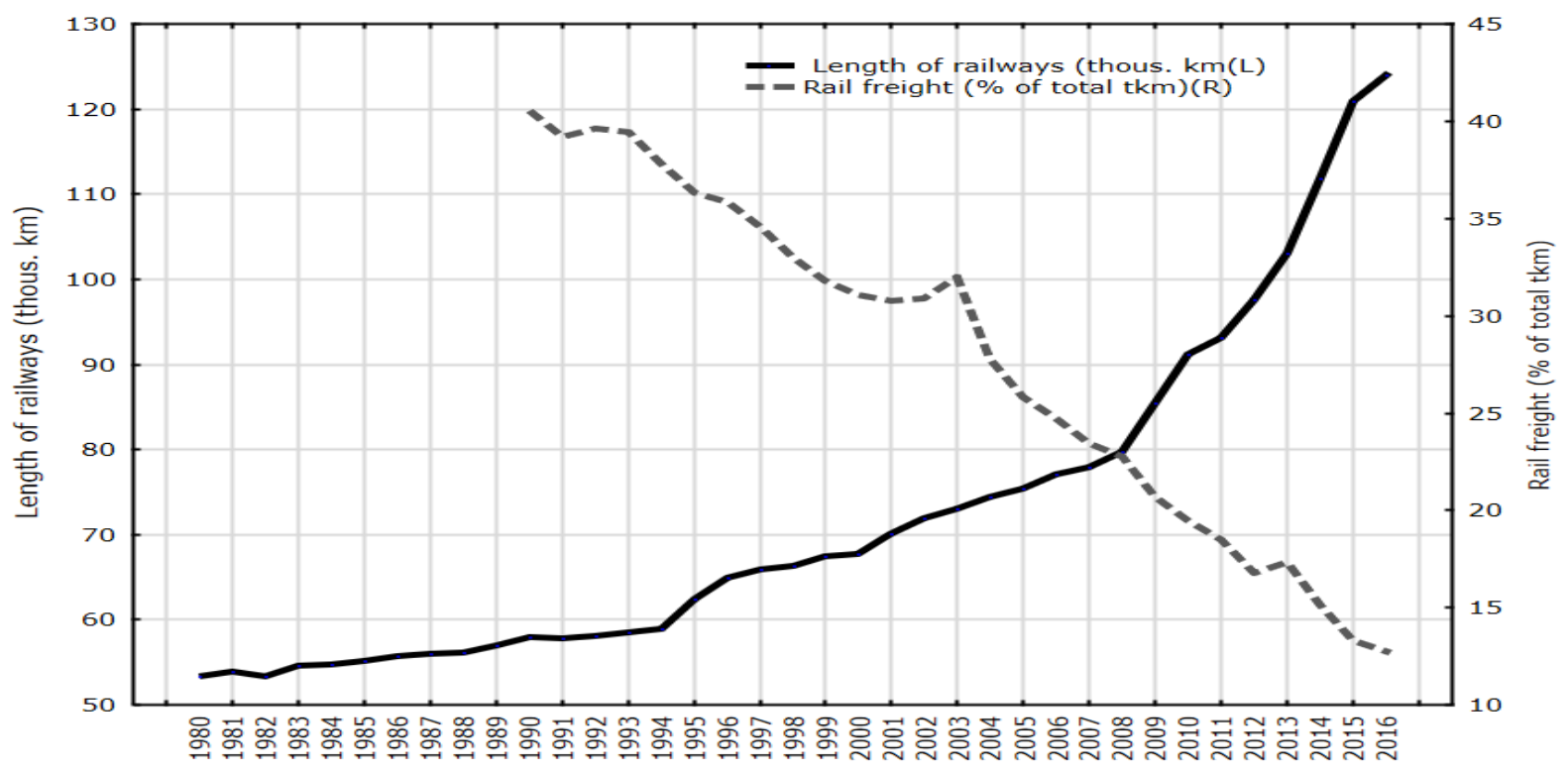

Source: author's calculations based on: China Statistical Book 2010-2016, Tab. 16-3 Length of Transportations Routes, Tab. 16-9 Freight Ton-Kilometres

Fig. 2. The length of railway lines and the share of railways in freight in China (1980-2016)

Out of $121,000 \mathrm{~km}$ of railways in China (2015), only $61.7 \%$ are electrified and $53.5 \%$ are dualtrack.

Given the volume of rail transport in China, it should be noted that:

1) the average annual growth in the volume of rail transport (1990-2015) was $5.22 \%$;

2 ) there is a downward trend in the volume of goods transported by rail, especially since 2010 . The average annual decrease is $-1.38 \%$ (2010-2015), although for $2015-2016$, it slowed down to $0.57 \%$; 
3) in the last two years, the volume of rail transport has fallen to the level recorded in 2007 and a record-breaking volume was reached in 2011 - approximately 2.95 trillion tkm.

The New Silk Route assumes the development of a transport network in many directions, both by sea, road and rail connections.

The New Eurasian Land Bridge, for example, is designed to connect Chinese provinces to Europe quickly by rail. Importantly, the congested eastern ports of China are being bypassed and, in addition, railways will influence the development of other western provinces of the central state and other regions of Asia.

It should be added that China, Japan and Germany are among the leading countries in the construction of the high-speed rail system. The Chinese have 12 thousand miles of fast railway, which is more than all (in total) other countries of the world. In addition, the Chinese build relatively cheaply and quickly, which gives them a significant advantage in competition with others. Unfortunately, this sector requires significant capital costs, the railways are more expensive to operate, and China Railway Corporation would have major economic problems under free market conditions (without State aid). It may be particularly difficult to implement fast connections in Russia and Kazakhstan, which are facing economic problems, or countries in Europe, which are experiencing an economic slowdown.

A high-speed Moscow-Beijing railway connection alone would be more than 4350 miles and cost more than 230 billion USD, but it would also reduce the time it takes to transport containers (TransSiberian railway) from six to two days.

Although rail transport is not an excellent substitute for maritime transport because in order to replace one container ship about 300 railway depots would have to be checked in, this transport is important for the creation of many connections in neighbouring countries, inside China and also with Europe.

In 2013, a railway connection was opened between China, Poland and Germany, and interestingly the freight time is 16 days and is three weeks shorter than by sea. The railway has also strengthened local development in the design and construction of other railway connections in Russia, Asia and China itself.

Cities such as Lianyungang (Jiangsu Province), Lanzhao, Wuhan, Chongqing, Xian and Urumqi are connected to Western European cities such as Rotterdam and Duisburg in Germany. Chinese goods reach Xinjiang through China's internal rail system. The railway connection runs through Kazakhstan, Russia, Belarus, Poland and the Czech Republic, Germany, to the shores of the Atlantic. This transcontinental railway line, using 39 existing sections, connects 16 Chinese cities with 12 European cities. An important role is played by logistics hubs.

Modal transport statistics for $28 \mathrm{EU}$ Member States suggest a slow increase in the importance of rail as a mode of transport, and so in 2010, rail transport accounted for $11.8 \%$ of total transport (tkm); in 2015, this percentage increased to $12.3 \%$; although in 2016, it decreased to $11.6 \%$ (Eurostat, 2016, 2017). It can be concluded that land transport between China and Europe is still underdeveloped and that there are strong needs in this respect, both in terms of growth in the volume of trade with China and in bilateral trade.

Rail transport should play a much greater role in EATL (Euro-Asian Transport Link) connections. The benefits of rail transport can be achieved through:

- development of cooperation between suppliers, terminal operators, transport companies, forwarding agents, etc.; 
- the ability to offer competitive freight prices, and respond in setting tariffs to changing market conditions,

- ensuring flexibility in the planning of individual directions of iron roads;

- international cooperation in long-distance transport.

There is No doubt that the railway sector needs to be reformed. To this end, a variety of strategies have been put in place, which are often dependent on individual regions. And for example:

- EU Member States are the initiators of the 4th Railway Package. The so-called technical pillar of the railway package consists of legislative acts: Regulation (EU) 2016/796 of the European Parliament and of the Council of 11 May 2016 on the European Union Railway Agency and repealing Regulation (EC) No 881/2004, Directive 2016/797 of the European Parliament and of the Council of 11 May 2016 on the interoperability of the rail system within the European Union, Directive 2016/798 of the European Parliament and of the Council of 11 May 2016 on railway safety. Article (1) justifies the objective of progressively establishing a single European railway area and the need to take measures to regulate railways, taking into account the technical aspects of safety and interoperability. Commission Implementing Regulation (EU) 2017/6 of 5 January 2017 on the European Deployment Plan for the European Rail Traffic Management System defines nine core network corridors: 1) Baltic Sea - Adriatic Sea, 2) North Sea - Baltic Sea, 3) Mediterranean Sea, 4) East/Eastern Mediterranean, 5) Scandinavia - Mediterranean, 6) Rhine Alps, 7) Atlantic, 8) North Sea - Mediterranean, (9) Rhine - Danube. Of the nine corridors, six run through Germany, two run through Poland, one through the Baltic States (Commission Implementing Regulation (EU) 2017/6, 2017);

- countries aiming at integration and membership with EU countries (Turkey, Bosnia and Herzegovina, Macedonia, Serbia, Montenegro) and aiming at integrating the railway network into the EU corridors;

- Russia and other countries of the former USSR, which have either developed their own model of reforms (Russia, Kazakhstan) or have made some reforms, but progress is moderate (Ukraine, Uzbekistan), or reforms are unlikely to have been undertaken (Belarus, Moldova, Tajikistan, Armenia, Azerbaijan, etc.);

- Asian countries that do not belong to any of the above groups, which are characterised by different, varied situations with regard to the development and reform plans in the railway sector (Afghanistan, China, Iran, Mongolia, Pakistan).

Railway transport can successfully compete with road transport, especially in long-distance and heavy-duty transport, while ensuring shorter delivery times. In addition, long-distance rail transport of cargo is relatively cheap, i.e. less than USD 0.03 per $1 \mathrm{tkm}$, and with a dense rail network, it can oscillate around USD 0.02 per $1 \mathrm{tkm}$. Rail transport is an important substitute for maritime and inland waterway transport, especially for regions remote from seas, ports, canals and navigable rivers. The electrified grid shall fit into the promotion of sustainable development and the reduction of greenhouse gas emissions. The development of rail transport results in a reduction in air emissions due to reduced road traffic (Environmental Impact Assessment..., 2018). In addition, the core corridors are to form the Trans-European Transport Network using the road, rail, seaports and inland waterways, inland waterways, airports, road-rail terminals. This network could be an important link between the EU countries and other areas and regions in Europe, as well as an important element of the NSR. 
In the case of railways, a major weakness in intercontinental connections may be delays in delivery as a result of: transport of goods across national borders, (different types of) inspections on both sides of the border, poor synchronisation of freight trains, which can lead to long waiting times at border stations, damage to goods, especially when locomotives are changed etc. The Commission will continue to take into account the fact that, in the case of railways, delays in the delivery of goods by rail can be a major weakness in intercontinental connections. Studies have shown that on the New Eurasian Land Transport Initiative (NELTI) route, $40 \%$ of transport time was spent at national borders (Railway Reform... , 2011). Undoubtedly, the development of modern railways can successfully lead to an increase in social welfare with the fulfilment of the idea of sustainable development.

\section{Conclusions, proposals, recommendations}

1) In the last decades of the 20th century and the early 21st century, rail freight has experienced a regression. In global trade, maritime and road transport play an increasingly important role. The New Silk Road Initiative, as well as European Union's transport policy, offer a great opportunity to reverse the downward trend in rail transport.

2) In the future, rail transport corridors will offer the possibility of transporting goods over long distances, which will make it possible to relieve road transport while at the same time being competitively priced (transport tariffs). The completion of the high-speed European rail network by 2050 and the tripling of the existing high-speed rail network by 2030 as well as the maintenance of a dense rail network in all Member States is the objective outlined in the White Paper.

3) Railways are the recommended means of transport to promote a policy of sustainable development in progressive globalisation, as exemplified by the NSR. The above is consistent with the assumptions adopted by the European Commission in the "White Paper" and Regulation (EU) No. 1316/2013, 2013 assuming a $60 \%$ reduction in emissions, including the full development of an integrated European railway market.

4) Existing and new railway connections may contribute to the stabilisation of supplies of goods and raw materials, as well as the time of their realisation, which will be significantly shortened from several dozen days to a dozen or so.

5) In addition to various types of barriers to the development of the global market, including barriers to the development of rail transport, there are technological barriers, procedural barriers, inadequate infrastructure, inefficient processes, inconsistent development of the transport policy and financial barriers. Therefore, a joint commitment by countries to promote the development of transport, including intermodal transport, is required, and the NSR offers an opportunity to do so.

\section{Bibliography}

1. China Statistical Yearbook, 2014-2017, National Bureau of Statistics of China, China Statistics Press, Beijing, Tab. 11-6 Value of Imports and Exports by Country (region) of Origin/destination, Tab. 16-3 Length of Transportations Routes, Tab. 16-9 Freight Ton- Kilometres, Tab. 16-8 Freight Traffic.

2. Commission Implementing Regulation (EU) $2017 / 6$ of 5 January 2017 on the European Rail Traffic Management System European deployment plan, Annex I, Official Journal of the European Union.

3. Eurostat. (2016, 2017) (online data codes: rail_go_typeall (rail), iww_go_atygo (inland waterways), road_go_ta_tott (national road transport), road_go_ca_c (road cabotage transport); Eurostat computations (international road transport, air and maritime transport).

4. Kunaka, Ch., Carruthers, R. (2014). Trade and Transport Corridor. Management Toolkit. Washington, World Bank, pp. XIII-XIV and next. 
5. Myszczyszyn (2013). Wplyw kolei zelaznych na wzrost gospodarczy Niemiec (1840-1913), Lodz.

6. Prognoza oddzialywania na srodowisko Projektu Strategii Zrownowazonego Rozwoju Transportu do 2030 roku. (2018), Warszawa

(https://www.gov.pl/documents/905843/1047987/Raport_nr_2_Prognoza_SRT_8XI2018.pdf/2f6da03e538c-7fbb-1fb5-4b94fbae60c1).

7. Puls, T. (2016). One Belt One Road - Chinas neue Seidenstraße, IW-Kurzberichte 67.

8. Railway Reform: Toolkit for Improving Rail Sector Performance, The International Bank for Reconstruction and Development. (2011). The World Bank, Washington, pp. 3, 48-49.

9. Regulation (EU) No 1316/2013 of the European Parliament and of the Council of 11 December 2013 establishing the Connecting Europe Facility, amending Regulation (EU) No 913/2010 and repealing Regulations (EC) No 680/2007 and (EC) No 67/2010, Official Journal of the European Union L 348/129.

10.Starr S. F, Cornell, S., E, Norling, N. (2015). The EU, Central Asia, and the Development of Continental Transport and Trade, Silk Road Paper, December, pp. 17.

11. Vision and Actions on Jointly Building Silk Road Economic Belt and 21st -Century Maritime Silk Road 2015/03/28. (2015). the National Development and Reform Commission, Ministry of Foreign Affairs, and Ministry of Commerce of the People's Republic of China, Supra note 28.

12. White Paper, Roadmap to a Single European Transport Area - Towards a competitive and resource efficient transport system, European Commission, Brussels, 28.3.2011.

13. World Trade Statistical Review 2016. (2016). World Trade Organization, pp. 16, 18, 134-138.

14. World Trade Statistical Review 2017. (2017). World Trade Organization, pp. 16, 148-155. 